\title{
VISUAL BERARGUMEN PADA PERINGATAN KESEHATAN BERGAMBAR
}

\author{
Rini Maulina \\ Universitas Komputer Indonesia \\ J. Dipati Ukur No.112-116, Lebakgede, Coblong, Kota Bandung, Jawa Barat 40132 \\ rini.maulina@email.unikom.ac.id
}

Diterima: 1 Juni 2018

Direvisi Akhir: 30 Juni 2018

Disetujui terbit: 3 Juli 2018

\begin{abstract}
Abstrak: Peringatan kesehatan bergambar adalah visual berargumen yang merupakan suatu kombinasi elemen visual dan verbal. Penelitian ini mengevaluasi efektivitas peringatan kesehatan bergambar yang berlaku di Indonesia, Singapura dan negara-negara anggota Dewan Kerja sama Teluk dengan penggunaan empat (4) metode dari para ahli komunikasi visual dan satu metode modifikasi dari penulis. Hasil evaluasi menunjukkan terdapat peringatan kesehatan bergambar yang efektif. Penelitian ini diharapkan dapat mencerahkan semua profesional dalam pengetahuan desain komunikasi visual.
\end{abstract}

Kata kunci: Argumen, Majas, Retorika, Visual, Tembakau

\begin{abstract}
The pictorial health warning is a visual argument that is a combination of visual and verbal elements. This study evaluates the effectiveness of pictorial health warnings applied in Indonesia, Singapore and Gulf Cooperation Council by using four methods from visual communication experts and a modification method from author. The evaluation results show that there are an effective picture health warnings. The research is expected to enlighten all professionals in visual communications design knowledge.
\end{abstract}

Keywords: Argument, Style, Rhetoric, Visual, Tobacco

Penulis adalah pengajar pada Program Studi Desain Komunikasi Visual, Universitas Komputer Indonesia 


\section{PENDAHULUAN}

Pencantuman peringatan kesehatan bergambar (Public Health Warning/ PHW) pada kemasan produk tembakau dimaksudkan untuk "lebih memvisualisasikan sekaligus menyebarluaskan informasi yang benar melalui edukasi dan pengetahuan kepada masyarakat tentang bahaya dari perilaku merokok" (Kemenkes RI, 2018). Peringatan kesehatan bergambar tidak hanya berlaku di Indonesia tetapi juga negara-negara lain (Tobacco Labelling Resource Centre, 2013).

Peraturan Menteri Kesehatan Nomor 28 Tahun 2013 (selanjutnya disebut PMK282013) Tentang Pencantuman Peringatan Kesehatan dan Informasi Kesehatan pada Kemasan Produk Tembakau mempersyaratkan antara lain:

(a) Pasal 1 titik 2 menjelaskan bahwa peringatan kesehatan adalah "gambar dan tulisan yang memberikan informasi mengenai bahaya merokok,"

(b) Pasal 3 titik 1: "Setiap orang yang memproduksi dan/atau mengimpor produk tembakau ke dalam wilayah Indonesia wajib mencantumkan peringatan kesehatan pada kemasan terkecil dan kemasan lebih besar produk tembakau,

(c) Pasal 3 titik 5 menetapkan lima (5) buah peringatan kesehatan. Kelima gambar dapat dilihat pada Gambar 1, 2, 3, 4, dan 5.

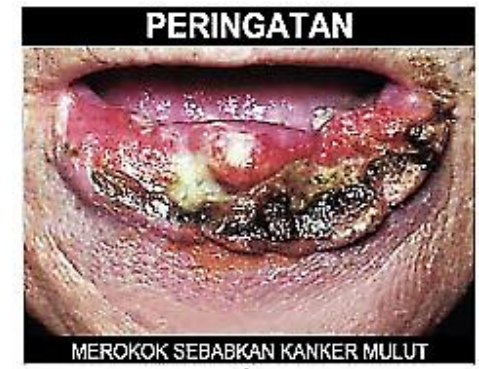

Gambar 1 Gambar Kanker Mulut Sumber: PMK282013

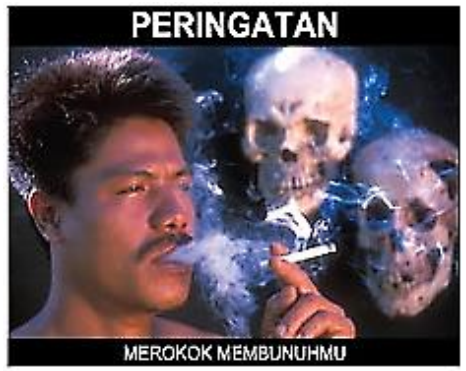

Gambar 2 Gambar orang merokok dengan asap yang membentuk tengkorak Sumber: PMK282013 


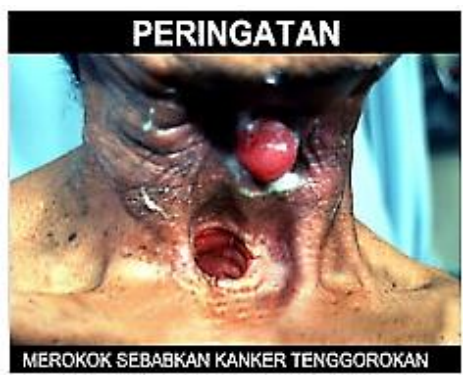

Gambar 3 Gambar kanker tenggorokan Sumber: PMK282013

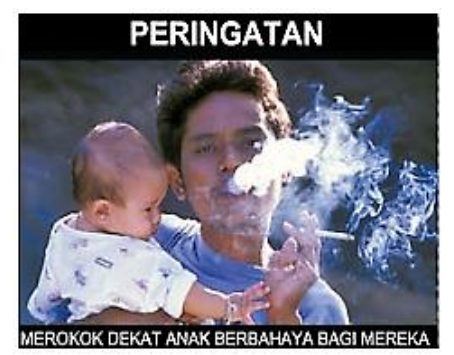

Gambar 4 Gambar orang merokok dengan anak di dekatnya Sumber: PMK282013

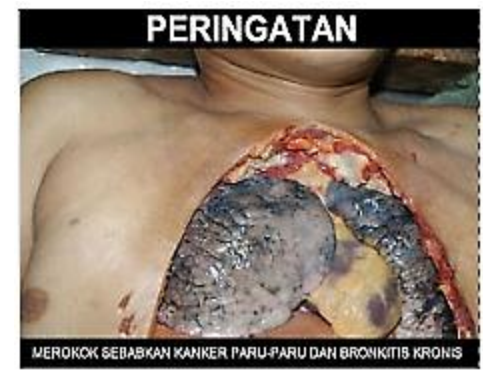

Gambar 5 Gambar paru-paru yang menghitam karena kanker Sumber: PMK282013

Fox (2013) menyatakan bahwa komunikator visual atau desainer komunikasi visual berperan, menggunakan kompetensi dan sumber daya yang dimilikinya, dalam merancang dan menganalisis pesan visual yang efektif. Sebuah visual berargumen dirancang melalui penerapan bahasa visual seperti tipografi, warna, tata ruang dan letak, serta gambar. Penelitian ini mengevaluasi peringatan kesehatan bergambar pada kemasan rokok dengan fokus untuk melihat efektivitas pesan kesehatan bergambar seperti dipersyaratkan para ahli komunikasi visual dan sebuah metode modifikasi dari penulis.

\section{KAJIAN TEORI}

Makna argumen menurut Kamus Besar Bahasa Indonesia (2018) adalah alasan yang dapat dipakai untuk memperkuat atau menolak suatu pendapat, pendirian, atau gagasan, sementara retorika dimaknai sebagai keterampilan berbahasa secara efektif. Salah satu cara mempengaruhi emosi pemirsa adalah 
menggunakan retorika. Rajiyem $(2005,143)$ menyatakan bahwa "Tujuan retorika terutama berusaha mempengaruhi pemirsa atau komunikan. Yang perlu diperhatikan ialah retorika merupakan teknik pemakaian bahasa secara efektif yang berarti keterampilan atau kemahiran dalam memilih kata-kata yang dapat mempengaruhi komunikan sesuai dengan kondisi dan situasi komunikan tersebut."

Fromilhague seperti dikutip oleh Nugroho (2012) menyatakan bahwa majas adalah salah satu unsur retorika. Menurut Kamus Besar Bahasa Indonesia (2018), majas dimaknai sebagai "cara melukiskan sesuatu dengan jalan menyamakannya dengan sesuatu yang lain."

Noble \& Bestley (2011) menyatakan bahwa istilah retorika visual "visual rhetoric" dan majas visual "visual style" dalam ilmu desain komunikasi visual atau desain grafis dapat dimaknai sama dengan pengertian pada ilmu Bahasa/ Sastra yang telah berkembang lebih dulu, seperti ironi (majas yang menyatakan makna yang bertentangan dengan makna sesungguhnya), hiperbol (majas yang menonjolkan suatu gagasan dengan ungkapan yang berlebih-lebihan atau dibesarbesarkan), dan simile (majas pertautan yang membandingkan dua hal yang secara hakiki berbeda, tetapi dianggap mengandung segi yang serupa, serta dimaksudkan untuk memperoleh efek tertentu).

Kopco (n.d.) menyatakan bahwa perbandingan yang menunjukkan adanya hubungan atau kemiripan adalah sangat penting dalam komunikasi visual. Menurut Barnet dan Bedau (2014), salah satu fungsi gambar yang disertakan pada argumen tertulis adalah agar gambar tersebut memersuasi melalui penggugahan emosi pemirsa. Sejalan dengan pernyataan tersebut Grancea (2017) menyatakan bahwa elemen gambar dalam media komunikasi visual, selain berfungsi untuk 
menyentuh emosi pemirsa, juga menguatkan, menjelaskan, menceritakan, atau mengilustrasikan pesan yang terkandung dalam elemen verbal.

Visual berargumen dimaknai sebagai desain komunikasi visual yang mengombinasikan elemen verbal, dapat berupa teks seperti pada produk desain grafis atau suara seperti pada video, film, televisi, animasi atau lainnya dengan elemen visual (Blair, 2004: 49). Ramage, Bean, dan Johnson (2016) menyatakan bahwa untuk memahami sebuah gambar dapat menghasilkan suatu argumen, desainer harus memahami bagaimana empat komponen dasar desain visual yaitu tipografi, tata ruang dan letak, warna, serta gambar berkoherensi menghasilkan sebuah teks visual. Sihombing (2015) dalam Septiningtyas dan Soewardikoen $(2018,5)$ menyatakan bahwa: "Tipografi merupakan salah satu elemen desain, di mana berfungsi untuk menunjang komunikasi yang memberikan pesan yang dapat dibaca secara jelas dan tepat, selain itu secara estetika pesan dapat terlihat menarik." Soewardikoen (2015) dalam Septiningtyas dan Soewardikoen $(2018,5)$ menyatakan "Ilustrasi dapat memudahkan pembaca untuk menggambarkan informasi. Tujuan utama dari sebuah ilustrasi adalah untuk menarik perhatian pembaca, serta untuk mengomunikasikan ide dan gagasan iklan sehingga iklan dapat dipercaya."

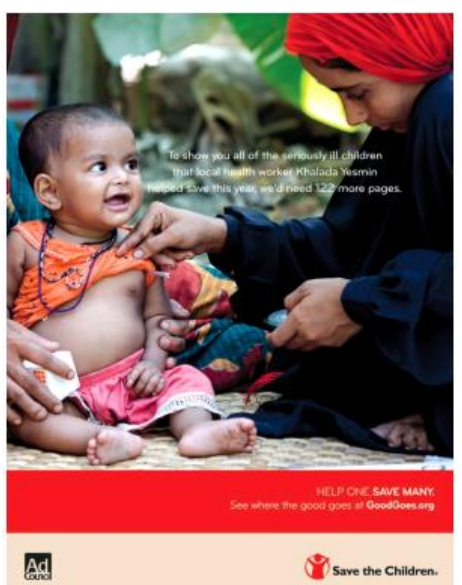

Gambar 6 Save the Children advocacy ad Sumber: Ramage, Bean, dan Johnson $(2016,181)$ 
Salah satu visual berargumen yang dievaluasi dapat dilihat pada Gambar 6 . Hasil evaluasi Ramage, Bean, dan Johnson (2016) adalah sebagai berikut: Iklan advokasi ini menggunakan elemen visual seperti warna, tata ruang dan letak, serta tipografi dengan elemen verbal untuk menafsirkan dan memperkuat pesan. Salah satu pesan iklan ini termuat pada teks yang tidak mencolok (dalam huruf putih kecil), yang mengarahkan mata pembaca dari wajah bayi ke dada pekerja kesehatan dengan muatan "Dibutuhkan 122 halaman lagi untuk menunjukkan bagaimana petugas kesehatan setempat di tahun ini, Khalda Yesmin, membantu anak-anak yang sakit." Dalam iklan ini, seorang bayi, pekerja kesehatan, dan sosok ketiga di luar bingkai foto duduk di atas tikar tenunan (pakaian orang-orang menunjukkan bahwa adegan ini terjadi di Bangladesh).

Penggunaan warna-warna cerah, menciptakan perasaan hangat dan cinta, posisi objek, bidikan close-up bayi dan pekerja kesehatan mengarahkan pemirsa ke adegan tersebut. Latar belakang menunjukkan kemungkinan besar, rumah ibu dan bayi, yang dikunjungi petugas kesehatan. Petugas kesehatan, dalam pakaian gelap dan jilbab merah, berkonsentrasi mengukur suhu badan bayi, menyiratkan keahliannya. Tangan Khalada Yesmin, bayi, dan ibu yang memegang bayi menimbulkan ide bahwa bantuan dapat meningkatkan tingkat kehidupan ibu dan anak melalui kasih dan pengetahuan. Teks di bagian bawah iklan "Membantu seorang. Menolong banyak" dan "Kemana kebaikan Anda disalurkan" memperluas wawasan pemirsa bahwa jika bantuan ditujukan untuk persediaan alat dan obatobatan serta untuk pelatihan tenaga kesehatan setempat, maka sumbangan dapat disebarkan lebih meluas.

Sejalan dengan pendapat di atas, Blakesley \& Hoogeveen (2012) menyatakan bahwa elemen visual dapat berdiri sendiri sebagai informasi dan argumen, tanpa tergantung pada hubungannya dengan elemen verbal. Gambar 7 
adalah sebuah visual berargumen, argumen pada gambar adalah menghimbau para pengemudi untuk mengemudikan kendaraannya dengan baik, tidak melebihi kecepatan yang diizinkan atau untuk menghindari permasalahan lebih lanjut yang mungkin timbul.

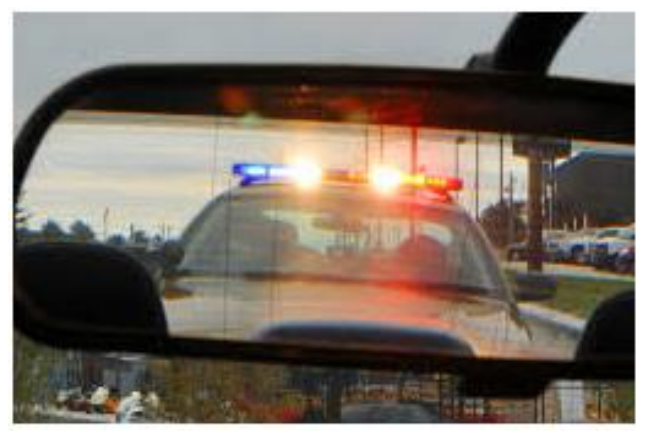

Gambar 7 Contoh visual berargumen

Sumber: https://www.carsguide.com.au/car-advice/what-should-i-do-when-i-hear-asiren-while-driving-55051

Elemen visual bertujuan untuk membantu pencapaian tujuan retorika dan peranannya dalam suatu desain komunikasi visual haruslah spesifik. Peran elemen visual terhadap elemen verbal, menurut Blakesley \& Hoogeveen (2012), dapat dibedakan menjadi dua, yaitu (1) sebagai ilustrasi dan penjelasan, berperan melengkapi deskripsi atau membantu menjelaskan informasi yang rumit, dan (2) sebagai analisis kandungan, elemen visual merupakan isi yang utama, dengan kata lain, elemen verbal dimaksudkan untuk memberitahukan kepada pemirsa tentang apa yang mereka lihat.

Visual berargumen memersuasi pemirsa dengan cara memberikan alasan dan prospek yang meyakinkan, sehingga pemirsa mau menerima gagasan atau perspektif tertentu. Dalam mendesain sebuah visual berargumen, terdapat tiga unsur yang perlu diterapkan oleh komunikator visual dalam rancangannya, ketiga unsur tersebut adalah 1) Klaim, 2) Fakta atau material pendukung, dan 3) asumsi. 
Klaim adalah pernyataan yang bersifat ringkas dan jelas, tentang suatu fakta atau kebenaran sesuatu. Klaim ini perlu didukung oleh bukti atau material pendukung, baik eksplisit maupun implisit, seperti testimoni, pendapat ahli, fakta berdasarkan pengalaman atau empiris, definisi, dan statistik. Asumsi merujuk kepada penerimaan pemirsa terhadap suatu klaim di mana pemirsa mengasumsikan adanya hubungan antara bukti atau material pendukung dengan klaim. Komunikator visual harus mengetahui karakteristik pemirsa yang ditujunya seperti tingkat literasi pemirsa dan jenis informasi yang dapat membujuknya (Institute for Global Tobacco Control, 2013). Grancea (2017) menyatakan bahwa jika penerapan elemen visual pada suatu desain komunikasi visual tidak mengubah makna dan argumen pada elemen verbalnya maka desain komunikasi visual tersebut bukanlah suatu visual berargumen.

\section{METODE PENELITIAN}

Penelitian ini adalah penelitian studi kasus dengan melakukan evaluasi peringatan kesehatan bergambar yang berlaku di beberapa negara yaitu Indonesia, Singapura, dan negara-negara peserta Dewan Kerjasama Teluk (GCC) dan difokuskan untuk melihat efektivitas peringatan kesehatan bergambar seperti dipersyaratkan para ahli komunikasi visual. Terinspirasi tulisan para ahli tersebut di atas, penulis mengajukan metode tanpa teks yaitu evaluasi visual berargumen hanya terhadap elemen visualnya saja tanpa mengkaitkannya dengan elemen verbal. Kamus Besar Bahasa Indonesia (2018) menyatakan bahwa makna evaluasi adalah "pengumpulan dan pengamatan dari berbagai macam bukti untuk mengukur dampak dan efektivitas dari suatu objek, program, atau proses berkaitan dengan spesifikasi dan persyaratan pengguna yang telah ditetapkan sebelumnya." 
Objek penelitian adalah peringatan kesehatan bergambar yang berlaku di Indonesia (2 buah, Gambar 2 dan Gambar 4), di negara-negara peserta Dewan Kerja sama Teluk (1 buah, Gambar 8), dan di Singapura (1 buah, Gambar 9).

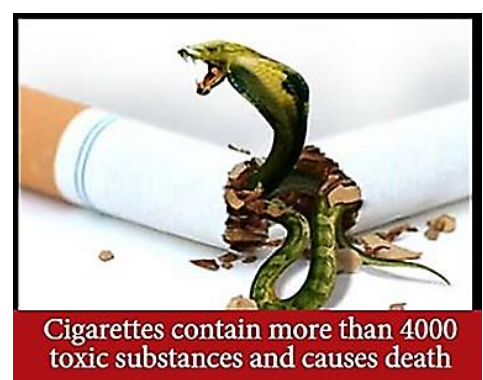

Gambar 8 Peringatan kesehatan bergambar yang berlaku di negara-negara peserta Dewan Kerjasama Teluk Sumber:

http://www.tobaccolabels.ca/countries/gulfcooperation-council/

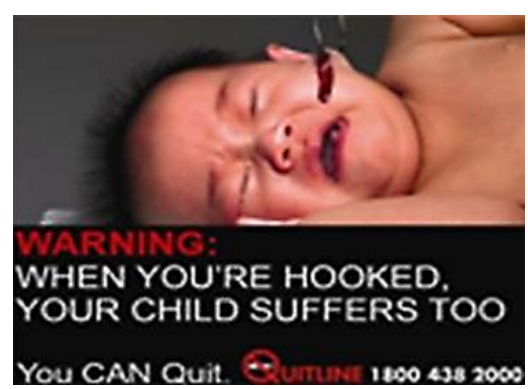

Gambar 9 Peringatan kesehatan bergambar yang berlaku di Singapura Sumber:

http://www.tobaccolabels.ca/countries/ singapore/

Kerangka berpikir yang dipergunakan dalam penelitian studi kasus ini terinisiasi dari keberadaan peringatan kesehatan bergambar pada kemasan rokok, mencari dan mengumpulkan materi-materi sehubungan tema yang terpilih, memilih dan menentukan objek penelitian, mengevaluasi objek penelitian berdasarkan metode-metode dari para ahli komunikasi visual dan modifikasi penulis, diakhiri dengan mengambil kesimpulan berdasarkan hasil evaluasi tersebut di atas. Kerangka berfikir dalam penelitian ini bukan suatu tahapan yang berhubungan secara linear, dimana pelaksanaan setiap tahapan tergantung selesainya tahap sebelumnya, tetapi lebih sebagai panduan dalam melaksanakan penelitian kualitatif. Kerangka berpikir tersebut dapat dilihat pada Gambar 10. 


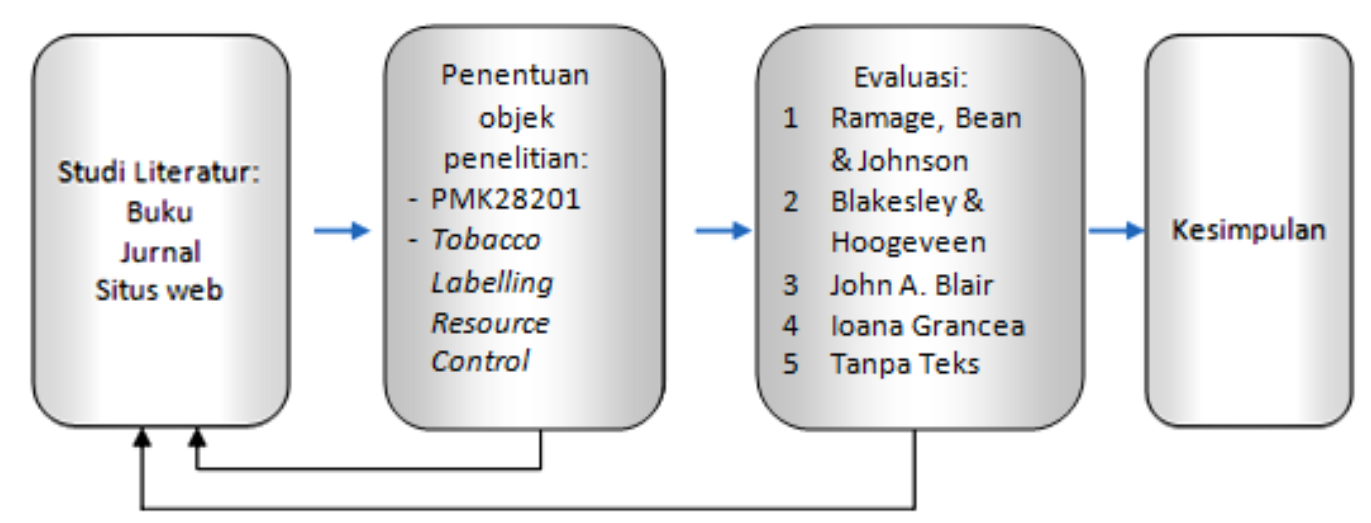

Gambar 10 Kerangka Berpikir Penelitian

(Sumber: Rini Maulina, 2018)

\section{HASIL DAN DISKUSI}

Evaluasi atas masing-masing peringatan kesehatan bergambar disajikan melalui tabulasi yang dapat dilihat pada Tabel 1 sampai dengan Tabel 4 . 
Tabel 1 Hasil evaluasi gambar orang merokok dengan asap yang membentuk tengkorak

\begin{tabular}{|c|c|}
\hline Metode & PERINGATAN \\
\hline $\begin{array}{l}\text { Ramage, Bean \& Johnson } \\
\qquad(2016)\end{array}$ & $\begin{array}{l}\text { Ruang didominasi elemen visual sehingga perhatian pemirsa } \\
\text { akan terarah kepada elemen ini, pemilihan warna gelap } \\
\text { menciptakan suasana dingin dan suram. Objek tengkorak lebih } \\
\text { bervolume dibanding asap rokok yang transparan sehingga } \\
\text { keduanya tidak membentuk satu kesatuan. Ekspresi perokok } \\
\text { kontradiktif dengan simbol tengkorak sebagai makna kematian. } \\
\text { Tidak didapati ciri khas kelndonesiaan pada elemen viual ini. } \\
\text { Cahaya dari atas (holy light) malah menimbulkan pemaknaan } \\
\text { dimuliakan. Teks "MEROKOK MEMBUNUHMU" dengan fonta } \\
\text { berwarna putih dengan ukuran kecil dan berlatar belakang hitam } \\
\text { memiliki tingkat keterbacaan rendah. }\end{array}$ \\
\hline $\begin{array}{l}\text { Blakesley \& Hoogeveen } \\
\qquad(2012)\end{array}$ & $\begin{array}{l}\text { Peran elemen visual sebagai analisis kandungan } \\
\text { Elemen visual yang dituju adalah menggambarkan orang } \\
\text { merokok dengan asap yang membentuk tengkorak. Pesan yang } \\
\text { ingin dimunculkan adalah orang yang memiliki perilaku merokok } \\
\text { tidak menyadari, ditunjukan dengan penggambaran ekspresi } \\
\text { perokok yang tampak menikmati hisapannya, bahwa dampak } \\
\text { terburuk dari perilaku tersebut adalah kematian, ditunjukan } \\
\text { melalui penggambaran tengkorak yang berasal dari asap rokok. } \\
\text { Namun demikian, tidak terlihat penggambaran dengan cara } \\
\text { bagaimana kematian (tengkorak) akan mengakibatkan kematian, } \\
\text { baik eksplisit maupun implisit. }\end{array}$ \\
\hline John Anthony Blair (2004) & $\begin{array}{l}\text { Majas visual yang dipergunakan adalah metafora yaitu kematian } \\
\text { diibaratkan sebagai tengkorak. Pada elemen visual tidak } \\
\text { ditemukan fakta atau bukti yang mendukung klaim bahwa } \\
\text { “MEROKOK MEMBUNUHMU.” Elemen visual memuat argumen } \\
\text { namun melemah dikarenakan kontradiksi antara objek manusia } \\
\text { dan tengkorak. }\end{array}$ \\
\hline Ioana Grancea (2017) & $\begin{array}{l}\text { Pesan dan argumen yang terdapat pada elemen verbal tidak } \\
\text { terpengaruh dengan penerapan elemen visual. }\end{array}$ \\
\hline Tanpa Teks & $\begin{array}{l}\text { Jika elemen verbal dihilangkan atau tidak diterapkan, beberapa } \\
\text { argumen pada elemen visual dapat dibangun oleh pemirsa } \\
\text { seperti melakukan ritual pemanggilan roh, merokok di tempat } \\
\text { angker, perokok berteman dengan hantu, perilaku merokok akan } \\
\text { mempercepat kematiannya, dan lain sebagainya. }\end{array}$ \\
\hline
\end{tabular}


Tabel 2 Hasil evaluasi peringatan kesehatan bergambar yang berlaku di negara-negara paserta Dewan Kerjasama Teluk

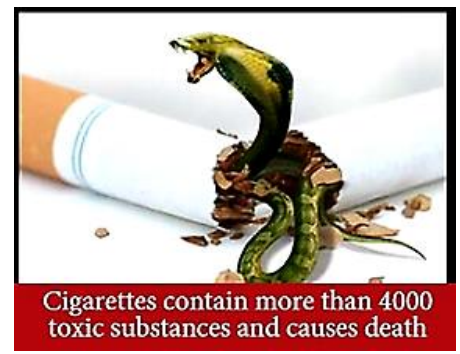

\begin{tabular}{cl}
\hline Metode & \multicolumn{1}{c}{ Uraian } \\
\hline & Elemen visual berupa sebatang rokok yang terpotong dua \\
& sehingga tembakaunya berserakan dan ilustrasi seekor ular \\
& berbisa yang keluar dari potongan rokok. Latar belakang elemen \\
& visual menggunakan warna putih menciptakan suasana netral \\
& (clear) sehingga objek ular berbisa menjadi fokus perhatian. \\
Ramage, Bean \& Johnson & Bidangnya berbingkai hitam tipis yang menyatu dengan bidang \\
& berisi teks sehingga menciptakan satu kesatuan. Fonta yang \\
(2016) & digunakan berukuran besar berwarna putih dan warna merah \\
& pada latar belakang teks dapat diartikan sebagai peringatan. \\
& Kombinasi fonta yang besar dan kontras dengan latar \\
& belakangnya meningkatkan keterbacaan teks. Tidak didapati ciri \\
& khas negara-negara peserta Dewan Kerjasama Teluk, baik pada \\
& objek maupun latar belakangnya. \\
\hline & Peran elemen visual sebagai ilustrasi \\
Pada elemen visual, sebatang rokok dikiaskan dengan seekor ular \\
berbisa. Serbuk tembakau yang terdapat pada potongan rokok \\
dan yang terserak menjelaskan banyaknya kandungan bahan \\
beracun. Elemen visual menggambarkan bisa ular sama dengan \\
racun, sehingga menghisap rokok sama dengan terkena bisa ular \\
yang beracun.
\end{tabular}

Elemen visual menggunakan majas visual simile dimana sebatang rokok dikiaskan seperti seekor ular berbisa dan kandungan bahan beracunnya diibaratkan sebagai bisa ular. Elemen visual John Anthony Blair (2004) tersebut jika tanpa disertai elemen verbal telah memuat argumen bahwa tembakau pada rokok dapat menyebabkan kematian. Asumsi pemirsa terbangun dari pemahaman bahwa racun pada bisa ular dapat menyebabkan kematian pada manusia.

Ioana Grancea (2017) Makna yang terdapat pada elemen verbal tetap sama namun argumentasinya berubah dengan penerapan elemen visual atau gambar.

Jika elemen verbal dihilangkan atau tidak diterapkan, tampak Tanpa Teks bahwa elemen visual memuat argumen bahwa perilaku merokok dapat menyebabkan kematian yaitu dengan mengumpamakan sebatang rokok seperti seekor ular berbisa. Hanya jumlah kandungan bahan beracun sebanyak 4.000 tidak tersalurkan. 
Tabel 3 Hasil evaluasi gambar orang merokok dengan anak di dekatnya

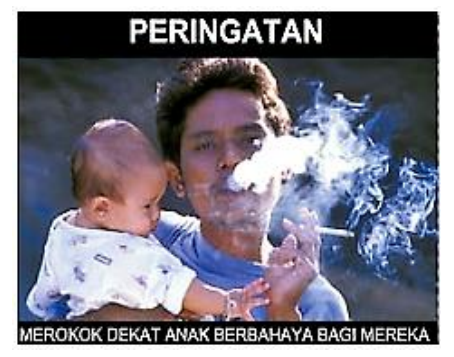

\begin{tabular}{|c|c|}
\hline Metode & Uraian \\
\hline $\begin{array}{l}\text { Ramage, Bean \& Johnson } \\
\qquad(2016)\end{array}$ & $\begin{array}{l}\text { Ruang didominasi elemen visual sehingga perhatian pemirsa } \\
\text { akan terarah kepada elemen ini, objeknya terdiri dari anak balita } \\
\text { yang sedang digendong oleh seorang laki-laki dewasa yang } \\
\text { sedang mengepulkan asap rokok. Penggambaran bahwa perilaku } \\
\text { merokok membahayakan bagi anak tidak tercapai karena anak } \\
\text { balita digambarkan dalam posisi nyaman dan arah asap rokok } \\
\text { yang menjauhinya. Tidak didapati ciri khas kelndonesiaan, baik } \\
\text { pada objek maupun latar belakangnya. Cahaya dari atas (holy } \\
\text { light) malah menimbulkan pemaknaan dimuliakan. Fonta } \\
\text { berwarna putih diatas latar belakang berwarna hitam sehingga } \\
\text { tingkat keterbacaannya rendah. }\end{array}$ \\
\hline $\begin{array}{l}\text { Blakesley \& Hoogeveen } \\
\qquad(2012)\end{array}$ & $\begin{array}{l}\text { Peran elemen visual sebagai ilustrasi } \\
\text { Elemen visual yang dituju adalah penggambaran orang merokok } \\
\text { dengan anak di dekatnya. Pesan yang ingin dimunculkan } \\
\text { mengambil tema Environmental Tobacco Smoke (ETS) yaitu } \\
\text { bahaya terhirupnya asap dari tembakau yang terbakar. } \\
\text { Pemilihan anak balita sudah tepat mengingat pemirsa meyakini } \\
\text { bahwa anak balita membutuhkan udara bersih dikarenakan } \\
\text { usianya yang masih berada dalam masa pertumbuhan. }\end{array}$ \\
\hline John Anthony Blair (2004) & $\begin{array}{l}\text { Elemen visual tidak mempergunakan majas dan penggunaan } \\
\text { tema Environmental Tobacco Smoke (ETS)/involuntary or passive } \\
\text { smoking atau secondhand smoke (National Cancer Institute, n.d.) } \\
\text { sejalan dengan anggapan atau keyakinan pemirsa tentang } \\
\text { adanya bahaya bagi perokok pasif. Pada elemen visual tidak } \\
\text { ditemukan fakta atau bukti yang mendukung klaim bahwa } \\
\text { merokok dekat anak berbahaya bagi anak tersebut. }\end{array}$ \\
\hline Ioana Grancea (2017) & $\begin{array}{l}\text { Makna dan argumen yang terdapat pada elemen verbal tidak } \\
\text { terpengaruh dengan penerapan elemen visual. }\end{array}$ \\
\hline Tanpa teks & $\begin{array}{l}\text { Jika elemen verbal dihilangkan atau tidak diterapkan terlihat } \\
\text { penggambaran orang yang merokok dengan anak di dekatnya. } \\
\text { Argumen yang dapat dibangun oleh pemirsa seperti kasih sayang } \\
\text { ayah terhadap anaknya, pentingnya hubungan antara ayah dan } \\
\text { anak, dan lain sebagainya. }\end{array}$ \\
\hline
\end{tabular}


Tabel 4 Hasil evaluasi peringatan kesehatan bergambar yang berlaku di Singapura

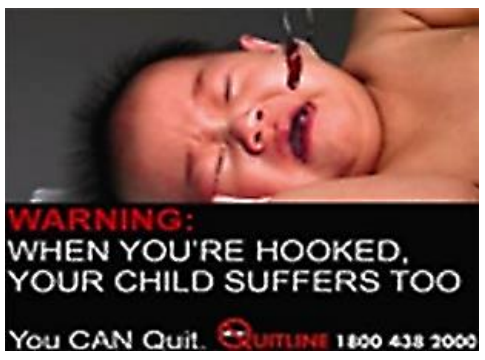

\begin{tabular}{cl}
\hline Metode & \multicolumn{1}{c}{ Uraian } \\
\hline Elemen visual berupa seorang anak bayi dalam posisi berbaring, \\
menangis kesakitan karena pipinya terkait mata pancing hingga \\
berdarah. Luas bidang elemen visual dan verbal seimbang. Latar \\
belakang berwarna gelap menciptakan suasana kelam, warna \\
terang pada anak bayi menjadikannya sebagai fokus. Fonta \\
berwarna putih berukuran besar berlatar belakang hitam \\
menjadikan teks mudah dibaca. Pilihan warna merah pada \\
beberapa teks menekankan pesan peringatan. Anak bayi yang \\
dipilih berasal dari kelompok etnis Tionghoa sebagai mayoritas \\
penduduk (77\%) di negara Singapura (Wikipedia, n.d.).
\end{tabular}

Peran elemen visual sebagai ilustrasi

Elemen visual yang dituju adalah penderitaan anak bayi yang berbaring menangis kesakitan karena pipi kirinya terkait mata pancing sehingga berdarah. Posisi anak bayi yang berbaring

Blakesley \& Hoogeveen miring menindih tangan kanannya menunjukan bahwa mata pancing yang terkait bukanlah karena tindakan kesengajaan tetapi menggambarkan adanya pihak lain yang akan menarik anak bayi. Pesannya adalah orang dewasa yang terpancing berperilaku merokok tidak hanya akan membuat dia sendiri yang menderita tetapi akan menyeret orang-orang terdekatnya (dalam hal ini anak) ke dalam penderitaan juga.

Majas visual yang diterapkan pada elemen visual adalah majas hiperbol, peluang terjadinya pipi anak bayi terkait mata pancing dalam kehidupan sehari-hari sangatlah kecil. Meskipun elemen visual merupakan hasil rekayasa digital, namun perhatian John Anthony Blair (2004) pemirsa akan tertuju pada bagian tersebut, sehingga pesan bahwa orang-orang terdekat (dalam hal ini anak) akan ikut terseret menderita akibat orang tua yang terpancing berperilaku merokok. Keberadaan teks "QUITLINE" pada elemen verbal sebagai bukti pendukung "evidence" terhadap klaim "WHEN YOU'RE HOOKED, YOUR CHILD SUFFERS TOO."

Ioana Grancea (2017) Pesan atau makna yang terdapat pada elemen verbal tetap sama namun argumennya menguat dengan penerapan elemen visual. Jika elemen verbal dihilangkan atau tidak diterapkan tampak Tanpa Teks bahwa elemen visual dapat diterapkan pada beberapa variasi klaim, seperti orang tua menjadi pecandu narkoba, pecandu miras, penjudi, dan lain sebagainya. 


\section{KESIMPULAN}

Berdasarkan data-data pada Tabel 1 hingga Tabel 4, pijakan kesimpulan diambil berdasarkan kandungan visual berargumen yang terdapat pada elemen visual dan elemen verbal pada masing-masing peringatan kesehatan bergambar dan disusun berurutan dimulai dari visual berargumen sangat efektif, efektif, cukup efektif dan kurang efektif, dengan penjabaran sebagai berikut:

Argumen pada Gambar 8: Elemen visual memuat argumen perilaku merokok menyebabkan kematian, objek gambar menguatkan argumen, bidang gambar lebih besar dari bidang teks, penggunaan majas visual simile berhasil. Elemen verbal memuat perilaku merokok menyebabkan kematian, ukuran fonta dapat terbaca, warna dan bidang pada latar belakang fonta meningkatkan keterbacaan teks. Penggabungan elemen visual dan verbal menjadikan visual berargumen tersebut sangat efektif.

Argumen pada Gambar 9: Elemen visual memuat argumen dampak perilaku merokok terhadap orang-orang di sekitarnya, objek gambar apabila disandingkan dengan teks menguatkan argumen, bidang gambar seimbang/ sama besar dengan bidang teks, penggunaan majas visual hiperbol berhasil.Elemen verbal memuat argumen dampak perilaku merokok terhadap orang-orang di sekitarnya, ukuran fonta besar mudah dibaca, warna dan bidang pada latar belakang fonta meningkatkan keterbacaan fonta. Penggabungan elemen visual dan verbal menjadikan visual berargumen tersebut efektif.

Argumen pada Gambar 2: Elemen visual memuat argumen dampak perilaku merokok dapat menyebabkan kematian namun lemah karena setiap objek pada elemen visual tidak saling mendukung argumen, bidang gambar mendominasi bidang teks, penggunaan majas metafora kurang berhasil. Elemen verbal memuat argumen dampak perilaku merokok dapat menyebabkan 
kematian, ukuran fonta kecil, warna dan bidang pada latar belakang fonta memiliki tingkat keterbacaan rendah. Penggabungan elemen visual dan verbal menjadikan visual berargumen tersebut cukup efektif.

Argumen pada Gambar 4: Elemen visual memuat argumen perilaku merokok dekat anak berbahaya bagi anak tersebut, namun sangat lemah karena setiap objek pada elemen visual tidak saling mendukung argumen, bidang gambar mendominasi bidang teks, tidak menggunakan majas apapun. Elemen verbal memuat argumen perilaku merokok dekat anak berbahaya bagi anak tersebut, ukuran fonta kecil, warna dan bidang pada latar belakang fonta memiliki tingkat keterbacaan rendah. Penggabungan elemen visual dan verbal menjadikan visual berargumen tersebut kurang efektif.

Peringatan kesehatan bergambar yang tercantum pada kemasan rokok adalah desain komunikasi visual berupa visual berargumen yang mengombinasikan elemen visual dan elemen verbal. Peringatan kesehatan bergambar yang berlaku di Indonesia memuat informasi tentang bahaya dari perilaku merokok pada elemen verbalnya.

Pelibatan para desainer komunikasi visual Indonesia dalam perancangan peringatan kesehatan bergambar diharapkan dapat menjadi pertimbangan pemerintah. Hal ini agar dapat menghasilkan rancangan yang sesuai dengan karakteristik penduduk Indonesia seperti tingkat literasi, retorika yang dipergunakan, tanda budaya, dan sebagainya.

\section{PERNYATAAN PENGHARGAAN}

Penulis mengucapkan terima kasih kepada Kementerian Riset Teknologi Dan Pendidikan Tinggi Republik Indonesia atas kesempatan dalam pendanaan pelaksanaan penelitian "Kajian Visualisasi Horror Iklan Layanan Masyarakat Peringatan Pemerintah tentang Bahaya Merokok sebagai Suatu Strategi Visual." 


\section{DAFTAR PUSTAKA}

Barnet, Sylvan, \& Bedau, Hugo, 2014. Critical thinking, reading, and writing. Boston: RR Donnelly-Crawfordsville.

Blair, J. Anthony. (Ed.), 2004. The Rhetoric of Visual Arguments. In:Charles A. Hill \& Marguerite Helmers, (Eds.) (2004). Defining Visual Rhetorics. London: Lawrence Erlbaum Associates, Inc., Publishers New Jersey. Ch. 2.

Blakesley, David \& Hoogeveen, Jeffrey L., 2012.Writing: A Manual for the Digital Age,Brief [e-book] 2nd Edition Wadsworth: Cengage Learning. Tersedia di <http://www.cengageasia.com/> [01 Mei 2018].

Fox, Randy, 2013. Visual rhetoric: An introduction for students of visual communication, [e-article], Colorado: AIGA Colorado. Tersedia di <https://colorado.aiga.org/2013/01/visual-rhetoric-an-introduction-forstudents-of-visual-communication/> [02 Juni 2018].

Grancea, loana, 2017. Types of Visual Arguments. Journal of the Seminar of Discursive Logic, Argumentation Theory and Rhetoric Argumentum [ejurnal], Vo.15 (2): 16-34. Tersedia di <https://www.fssp.uaic.ro/ argumentum/Numarul\%2015\%20issue\%202/02_I_Grancea_tehno\%20.pdf. $>$ [03 Mei 2018:19.00WIB].

Institute for Global Tobacco Control, 2013. State of evidence review: Health warning labels on tobacco products. [e-article]. Baltimore, MD: Johns Hopkins Bloomberg School of Public Health. Tersedia di <https://global tobaccocontrol.org/sites/default/files/HealthWarnings_state_of_evidence _final_11_18_2013_web_0.pdf>. [05 Juni 2018].

Kementerian Kesehatan Republik Indonesia, 2018. Peringatan kesehatan bergambar di kemasan rokok diperbaharui. [e-article] Tersedia di <http://www.depkes.go.id/article/print/18060400003/peringatan- 
kesehatan-bergambar-di-kemasan-rokok-diperbaharui-.html.> [02 Juni 2018].

------- Peraturan Menteri Kesehatan Nomor 28 Tahun 2013 Tentang Pencantuman Peringatan Kesehatan dan Informasi Kesehatan pada Kemasan Produk Tembakau.

Kementerian Pendidikan Dan Kebudayaan Republik Indonesia, 2018. KBBI Daring [e-dictionary] Tersedia di <https://kbbi.kemdikbud.go.id/> [01 Mei 2018]. Kopco, Paul, n.d. language as a model for graphic design - intro [e-article] Tersedia di <https://language as a model for graphic design - intro> [01 Mei 2018]. National Cancer Institute, n.d.. NCl Dictionary of cancer terms. [e-dictionary]. Tersedia di https://www.cancer.gov/publications/dictionaries/cancerterms/def/environmental-tobacco-smoke. [01 Mei 2018].

Noble, Ian and Bestley, Russell, 2011. Visual research: An introduction to research methodologies in graphic design. Edisi II, Switzerland: AVA Publishing SA.

Nugroho, R. Bagus, 2012. Strategi penggunaan retorika dalam iklan otomotif pada media berbahasa Perancis. Students e-Journal, [S.I.], v. 1, n. 1, p. 2, aug. 2012. Tersedia di <http://jurnal.unpad.ac.id/ejournal/article/view/ 909>. Tanggal Akses: 29 june 2018.

Rajiyem, 2005. Sejarah dan perkembangan retorika. Jurnal Humaniora, [e-journal] 17(2), [142-153]. Tersedia di <https://journal.ugm.ac.id/jurnalhumaniora/article/view/839> [01 Mei 2018].

Ramage, John D., Bean, John C., and Johnson, June, 2016. Writting arguments: a Rhetoric with reading. $10^{\text {th }}$ ed. USA:Pearson Education Inc.

Septiningtyas, Azizah dan Soewardikoen, Didit Widiatmoko, 2018. Perancangan identitas visual dan promosi Sasirangan Banjarbaru. Jurnal Desain Komunikasi Visual, Manajemen Desain dan Periklanan (Demandia) [ejournal], [1-17]. Tersedia di <http://journals.telkomuniversity.ac.id/

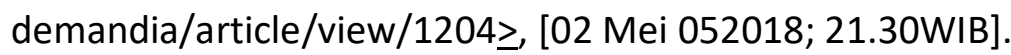


Tobacco Labelling Resource Centre, 2013. Health Warnings. [e-article]. Tersedia di <http://www.tobaccolabels.ca/healthwarningimages/>. [05 Juni 2018].

------ n.d. Demografi Singapura. [e-article]. Tersedia di < https://id.wikipedia. org/wiki/Demografi Singapura>. [15 Juni 2018]. 